\title{
Peningkatan Kemampuan Berpikir Kreatif Siswa melalui Model Pembelajaran Kooperatif Tipe Numbered Heads Together (NHT) pada Materi Lingkaran
}

\author{
${ }^{1}$ Muksin Djuanda, ${ }^{2}$ Yahya Hairun, ${ }^{3}$ Hery Suharna \\ ${ }^{1,2,3}$ Program Studi Pendidikan Matematika, Universitas Khairun
}

\begin{abstract}
ABSTRAK
Penelitian ini bertujuan untuk mengetahui: 1) Bagaimana kemampuan berpikir kreatif siswa setelah diterapkan model pembelajaran NHT, 2) Apakah terdapat peningkatan kemampuan berpikir kreatif matematis siswa pada materi lingkaran setelah di terapkan model pembelajaran kooperatif tipe NHT, 3) Bagaimana peningkatan kemampuan berpikir kreatif matematis siswa pada materi lingkaran setelah diterapakan model pembelajaran kooperatif tipe NHT.

Metode yang digunakan dalam penelitian ini adalah metode Pre-xsperimental Design dengan desain penelitian One Group Pretest-Posttest Design. Penelitian ini menggunakan satu kelas yaitu kelas yang diterapkan model NHT. Populasi pada penelitian ini adalah siswa kelas VIII SMP Negeri 1 Kota Ternate yang tersebar dalam 9 kelas dengan jumlah populasi 288 siswa. Dari kelas yang ada, kelas yang dijadikan sebagai sampel penelitian yaitu kelas VIII-E yang akan diberi perlakuan model NHT. Instrumen yang digunakan untuk mengumpulkan data adalah berupa soal tes uraian yang berjumlah 3 soal.

Hasil penelitian menunjukkan bahwa: 1) tingkat kemampuan berpikir kreatif matematis siswa setelah diterapkan model pembelajaranNHTdiperoleh 39\% (9 orang) di kualifikasikan sangat baik, 30\% (7 orang) baik, 13\% (3 orang) cukup, 9\% (2 orang) kurang, dan gagal 9\% (2 orang), 2) Terdapat peningkatan kemampuan berpikir kreatif matematis siswa setelah di terapkan Model pembelajaran Number Head Together (NHT) pada materi lingkaran, untuk uji normalitas data tes akhir dengan menggunakan programsofwareSpss diperolehsig. $0,054>$ nilai $\alpha=0,05$, artinya data atau sampelnya berdistribusi normal, sehingga digunakanuji statistik parametrik yaitu uji t. Dengandemikian berdasarkan nilai $t_{\text {hitung }}=3,200 t_{\text {tabel }}=2,080$ karna $t_{\text {hitung }}>$ $t_{\text {tabel }}$ maka kesimpulannya Ho ditolak dan $\mathrm{H}_{1}$ diterima artinya terdapat peningkatan kemampuan berpikir kreatif matematis siswa pada materi sistem persamaan linear dua variabel melalui penerapan model pembelajaran kooperatif tipe NHT, 3) Peningkatan kemampuan berpikir kreatif matematis siswa kelas VIII-E SMP Negeri 1 Kota ternate setelah diterapkannya model pembelajaran kooperatif tipe Number Head Together (NHT) yaitu 0,58 yang diinterpretasikan sedang.
\end{abstract}

Kata Kunci:Kemampuan Berpikir Kreatif Siswa, Pembelajaran Kooperatif Tipe Numbered Head Together (NHT) 


\section{PENDAHULUAN}

Salah satu penentu maju mundurnya suatu bangsa adalah pendidikan. Pendidikan memiliki peranan yang sangat penting dalam mempersiapkan generasigenerasi bangsa yang mampu mengimbangni laju perkembangan ilmu pengetahuan dan teknologi. Pembangunan dalam bidang pendidikan mendapat perhatian yang sangat besar dari pemerintah. Hal ini menjadi suatu keharusan dalam rangka mewujudkan tercapainya tinjauan nasional sebagaimana tercantum dalam pembukaan Undang-Undang Dasar 1945 yaitu mencerdaskan kehidupan bangsa.

Mencapai tujian tersebut juga di cantumkan melalui Undang-Undang RI Nomor 20 tahun 2003 tentang Sistem Pendidikan Nasional pasal 1, bahwa pendidikan merupakan usaha sadar dan terencana dan mewujudkan suasana belajar dan proses pembelajaran agar peserta didik secara aktif mengembagkan potensi dirinya untuk memiliki kekuatan spiritual keagamaan, pengendalian diri, kecerdasan, akhlak mulia, serta ketrampilan yang diperlukan dirinya, masyarakat, bangsa dan negara. Penciptaan potensi peserta didik dilancarakan memalui proses pembelajaran di setiap sekolah dengan sejumlah bidang ilmu penegetahuan.

Pendidikan merupakan hubungan antara pribadi pendidik dan peserta didik. Pergaulan terjadi kontak atau komunikasi antara masing-masing pribadi. Hubungan sosial ini jika mengingat ketaraf hubungan pendidikan, maka menjadi hubungan antara pendidik dan peserta didik, yang pada akhirnya melahirkan rasa tanggung jawab pendidikan dan kewibawaan. Pendidikan bertindak demi kepentingan dan proses pembelajaran dan kehidupan manusia, termasuk pembelajaran matematika. Matematika sebagai salah satu pelajaran yang berfungsi mengembangkan kemampuan menghitung, mengukur dan mengembangkan rumus matematika yang digunakan dalam kehidupan sehari-hari. Matematiaka merupakan salah satu disiplin ilmu yang menjadi pendukung bagi keberadaan ilmu-ilmu lain, Oleh karena itu siswa di harapkan memiliki penguasahan matematika pada tingkat tertentu, sehingga berguna bagi siswa keselamatan anak didik, dan anak didik mengakui kewibawaan pendidik dan bergantung padanya (Hasbullah, 2011: 5).

Matematika bukanlah ilmu yang berisi hafalan rumus belaka, siswa tidak hanya sekedar menerima rumus dari guru dan menghafalnya namun siswa harus mengetahui bagaimana rumus itu bisa terjadi dan di gunakan. Matematika berfungsi mengembangkan kemampuan menghitung, mngukur, menurunkan dan menggunakan rumus matematika yang di perlukan dalam kehidupan sehari-hari. Oleh karena itu, dalam pembelajaran matematika siswa harus dilibatkan secara aktif agar dapat membentuk keterampilan dan siswa dapat membangun pengetahuannya. Sebagaimana menurut Suparno (Sahrudin, 2014: 1-2).

Pembelajaran matematika pada hakekatnya bertujuaan untuk melatih siswa berpikir logis, kritis, analitis, dan sistematis. Semua kemampuan ini bertujuan agar siswa dapat berpikir aktif. Tetapi, dalam upaya meningkatkan kemampuan berpikir kreatif dalam matematika jarang atau tidak perna dikembangkan. Padahal kemapuan 
ini yang sangat diperlukan agar peserta didik dapat memiliki kemampuan memperoleh, mengelolah, dan memanfaatka informasi untuk bertahan hidup pada keadaan yang selalu berubah tidak pasti, dan kompetitif (fauziyah dkk, 2013: 76-77).

Ciri kemampuan berpikir kreatif yaitu kefasihan, fleksibilitas, orisinalitas, dan elaborasi. Kefasihan adalah kemampuan untuk menghasilkan pemikiran yang tepat. Fleksibilitas adalah kemampuan yang menghasilkan banyak macam pemikiran dan muda berpindah dari jenis pemikiran tertentu pada jenis pemikirannya. Orisinalitas adalah kemampuan untuk berpikir dengan cara baru dengan ungkapan yang unik, dan dan kemampuan untuk menghasilkan pemikiran-pemikiran yang tidak lazim dari pada pemikiran yang jelas diketahui. Elaborasi adalah kemampuan untuk menambah atau mencari hal-hal yang detail dari suatu objek, gagasan, atau situasi. Aspek-aspek itu banyak digunakan untuk mengukur kemampuan berpikir kreatif yang bersifat umum dan penekanannya pada produk kreatif, Siswono (Fajriah \& Asiskawati, 2015: 159).

Berpikir kreatif merupakan masalah penting dalam belajar matematika berpikir kreatif dapat membawa pengaru yang baik bagi siswa. Setiap orang harus memiliki kemampuan berfikir kreatif, mungkin tanpa berpikir kreatif siswa akan merasa kesulitan. Kekreatifan dapat membedakan siswa satu dengan siswa lainya, kerena siswa yang kreatif akan lebih maju dari siswa lainnya dan selalu banyak ide untuk menghasilkan sesuatu yang baru, sehingga kemampuan berpikir kreatif dapat menghasikan prestasi belajar siswa. Indicator berpikir kretif dan sesuai dengan bidang kajiannya. Menurut Siswono dkk ( Fajriah \& Asiskawati, 2015: 159) misalnya dalam matematika yang menekankan pada tiga indikator, yaitu kelancaran (kefasihan), keleluasan (flesibilitas), dan elaborasi (Elaboration).

Untuk meciptakan suasana yang menumbuhkan gairah belajar, meningkatkan hasil belajar siswa, mereka memerlukan perorganisasian proses belajar yang baik. Proses mengajar merupaka suatu rentetan kegiatan gurumenumbukan organisasi proses belajar mengajar yang efektif, yang meliputi tujuan pengajaran, pengaturan penggunaan waktu luang, pengaturan ruangan, dan alat perlengkapan belajar di kelas, serta pengelompokan siswa dalam belajar (Djamarah dan Zain, 2002: 38).

Menurut pendapat Sadiman dkk. (2002: 123) guru adalah " komponen manusiawi dalam proses belajar mengajar yang ikut berperan dalam usaha pembentukan sumber daya manusia yang potensial di bidang pembangunan'.

Dari kedua pendapat di atas, dapat disimpulkan bahwa guru merupakan salah satu komponen yang sangat berpengaruh pada proses pembelajaran, karena guru memegang paranan yang sangat penting antara lain menyiapkan materi, manyampaikan materi, serta tanggung jawab dan mengatur semua kegiatan belajar mengajar dalam proses pembelajaran. Oleh karena itu, sebagai salah satu tercapainya tujuan pembelajaran guru harus selalu mengetahui tujuannya sebagai seorang tenaga didik.

Dari sekian banyak mata pelajaran di sekolah, salah satu mata pelajaran yang sangat perlu menggunakan model atau metode yaitu pembelajaran matematika. Kebanyakan peserta didik berpendapat bahwa Matematika adalah mata pelajaran yang sulit dan membosankan. Menurut beberapa siswa alasan yang dipaparkan ketika 
ditanya terkait dengan alasan mereka beranggapan matematika sulit adalah karena mereka kurang begitu paham pentingnya konsep matematika dalam kehidupan seharihari, dan alasan mereka berpendapat mengapa matematika dianggap membosankan adalah karena pembelajaran matematika kurang diimbangi dengan permainan sehingga matematika akan bersifat lebih menyenangkan dan akan menarik minat para peserta didik sehingga pembelajaran akan bersifat lebih aktif.

Berdasarkan hasil tes awal yang dilakukan pada tanggal 28 Maret 2017 terdirih dari 4 butir soal. Untuk soal nomor 1 dan 2 Aspek yang diukur yaitu aspek kemampuan berpikir kreatif matematis, dengan indikator yaitu sebagai berikut: 1) keterampilan berpikir lancar (fluency). Sedangkan untuk soal nomor 3 dan 4, dengan indicator yang di gunakan sebagai berikut: 1) keterampilan berpikir luwes (flexibility). Berikut soal dan hasil sampel dari pengerjaan soal nomor di nomor 1 dan 2 .

1. Ibu membuat alas gelas berbentuk lingkran berdiameter $4 \mathrm{~cm}$, alas gelas yang terbuat dari bahan teripleks. Tentukan luas alas gelas tersebut.

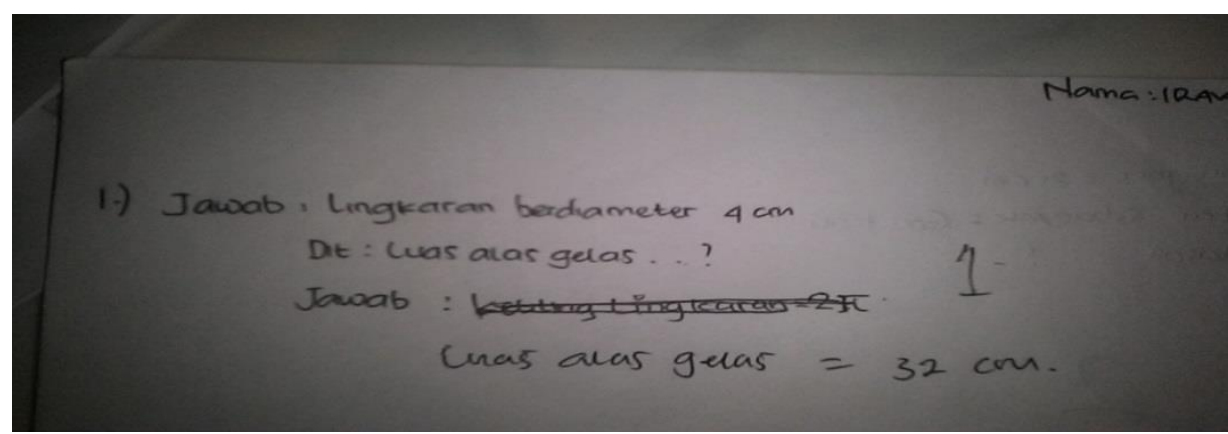

Gambar 1

Hasil pekerjaan siswa A pada nomor 1

2. Sebuah lingkaran memiliki luas $1386 \mathrm{~cm}^{2}$. Hitunglah jari-jari lingkaran tersebut.

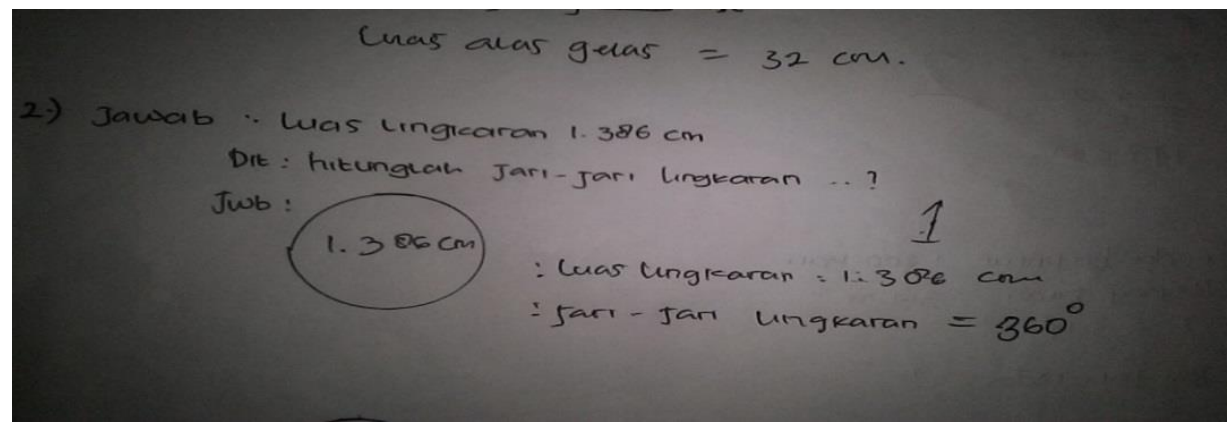

Gambar 2

Hasil pekerjaan siswa B pada nomor 2 
Berdasarkan gambar 1 dan 2, siswa belum dapat menuliskan objek yang diketahui di dalam soal tersebut. Hal ini menunjukan bahwa siswa belum mampu merumuskan masalah matematika secara tepat atau dengan kata lain siswa belum mampu berpikir lancar (Fluency). Selain itu, dalam Elaborasi siswa siswa tidak memperinci jawaban masalah matematikanya. Dengan demikian menunjukan bahwa siswa tersebut tidak memiliki kemampuan memperinci jawaban masalah matematika atau dengan kata lain siswa belum mampu berpikir Elaborasi.

Berdasarkan hasil tes kemampuan awal yang dilakukan pada tanggal 28 Maret 2017 bertempat di SMP Negeri 1 Ternate kelas VIII-E diperoleh bahwa banyak peserta didik yang belum dapat menjawab soal yang diberikan, khususnya soal pemecahan masalah yang diberikan. Berikut disediakan hasil kemampuan tes awal dalam bentuk diagram lingkaran.

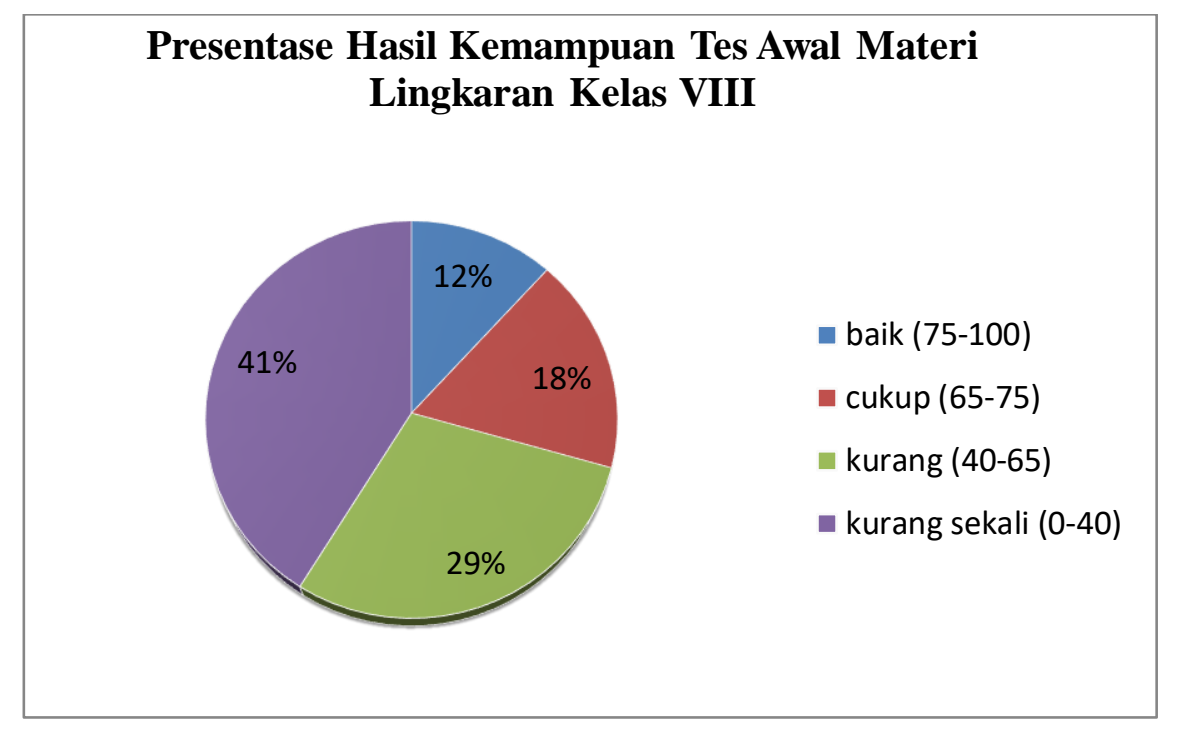

Diagram lingkaran diatas mengartikan dari 20 siswa kelas VIII, tidak ada siswa yang mendapat nilai dengan kategori baik (75-100), 4 orang kategori Cukup (65-75), 8 orang kategori kurang (40-65), dan 8 orang kategori kurang sekali $(\leq 40)$. Dari hasil persentasi grafik di atas dan KKM yang ditetapkan, dapat disimpulkan bahwa dari 18 siswa, tidak ada siswa yang mencapai nilai ketuntasan minimal. Sedangkan yang tidak memenuhi kriteria ketuntasan sebanyak 90\%. Hampir 100\% siswa tidak mampu menjawab soal dengan benar. Jelas bahwa, tujuan pembelajaran yang ditetapkan belum tercapai secara optimal. Untuk mencapai tujuan pembelajaran yang ditetapkan, diharapkan keberhasilan siswa dapat dicapai minimal 50\%. Namun, kenyataan yang diperoleh tidak sesuai harapan. Hal ini berarti terdapat masalah pada siswa kelas VIII SMP Negeri 1 Ternate pada materi lingkaran tahun ajaran $2017 / 2018$. 
Berdasarkan latar belakang di atas peneliti tertarik melakukan penelitian dengan judul "Peningkatan Kemampuan Berpikir Kreatif Matematis Siswa Pada materi lingkaran Melalui Model Pembelajaran Number Head Together (NHT)"

\section{METODE PENELITIAN}

Penelitian ini bertempat di SMP 1 Kota Ternate, Kecamatan Ternate Tenga, Kota Ternate, Provinsi Maluku Utara dan waktu pelaksanaannya mulai dari 7 Mei sampai 14 Mei 2018.Metode yang digunakan dalam penelitian ini adalah metode Prexsperimental Design dengan desain penelitian One Group Pretest-Posttest Design. Penelitian ini menggunakan satu kelas yaitu kelas yang diterapkan model NHT. Populasi pada penelitian ini adalah siswa kelas VIII SMP Negeri 1 Kota Ternate yang tersebar dalam 9 kelas dengan jumlah populasi 288 siswa. Dari kelas yang ada, kelas yang dijadikan sebagai sampel penelitian yaitu kelas VIII-E yang akan diberi perlakuan model NHT. Instrumen yang digunakan untuk mengumpulkan data adalah berupa soal tes uraian yang berjumlah 3 soal. Dalam penelitian ini yang diekperimenkan adalah model pembelajaran kooperatif tipe NHT (Number Heads Together), sedangkan desain penelitiannya yaitu One Group Design Pretest-Postest Purposif Sample (Sugiyono, 2010: 120). Desain penelitian ini merupakan rancangan penelitian yang melibatkan satu kelompok.Populasi dalam penelitian yang di rencanakan ini adalah seluruh siswa kelas VIIISMP NEGERI 1 Kota Ternate pada semester genap tahun ajaran 2018/2019. Jumlah kelas VIIISMP NEGERI 1 Kota Ternate sebanyak 9 kelas paralel. Jumlah populasi dalam penelitian ini 288 siswa yang tersebar di 9 kelas. Penempatan siswa kelas VIII SMP NEGERI 1 Kota Ternate dilakukan secara merata dalam hal kemampuan, artinya ada 2 kelas unggulan serta kurikulum yang diberikan juga sama, maka karakteristik antar kelas dapat dikatakan homogen, sedangkan karakteristik dalam kelas cukup heterogen, artinya ada siswa yang memiliki kemampuan tinggi, sedang, dan rendah. Dengan demikian maka Sampel dalam penelitian ini yaitu siswa kelas VIII-E SMP NEGERI 1 Kota Ternate yang berjumlah 23 siswa. Dalam penelitian ini terdapat dua variabel yaitu variabel bebas (X) dan variabel terikat $(\mathrm{Y})$. Variabel bebasnya yakni modelpembelajaran kooperatif tipe NHT (Number Heads Together), sedangkan variabel terikatnya adalah Kemampuan Berpikir Kreatif Matematis Siswa.

Teknik pengumpulan data yang digunakan dalam penelitian ini berupa tes uraian yang diberikan kepada siswa kelas VIII-ESMP NEGERI 1 Kota Ternate. Soal tes yang diberikan adalah soal-soal uraian dari materi lingkaran. Soal-soal tersebut dibuat dalam bentuk soal uraian yang merupakan soal-soal berpikir kreatif. Pemberian tes terdiri atas dua bagian yaitu tes sebelum perlakuan (pretest) dan tes setelah perlakuan (posttest). Pretest diberikan untuk mengukur kemampuan awal siswa terhadap materi yang diajarkan sedangkan posttest diberikan untuk mengukur kemampuan berpikir kreatif matematis siswa setelah mendapat perlakuan pembelajaran menggunakan model pembelajaran kooperatif tipe NHT (Number Heads Together). 
Analisis yang dilakukan adalah analisis deskriptif, analisis inferensial dan rumus Gainternormalisasi ( $N$-gain). Analaisis deskriptif digunakan untuk melihat bagaimana tingkat kemampuan berpikir kreatif matematis siswa setelah diterapkan model pembelajaranNHT dengan menggunakan mengkonversi skor yang didapat ke dalam bentuk presentase dan mengkategorikan kemampuan berpikir kreatif siswa seperti pada tabel di bawah ini, Riduwan (Ika Humaeroh, 2016, 71).

Tabel 1.

Interpretasi Tingkat Berpikir Kreatif Siswa

\begin{tabular}{|c|c|}
\hline $\begin{array}{c}\text { Presentase pencapaian } \\
\text { aspek berpikir kreatif }\end{array}$ & $\begin{array}{c}\text { Kategori Tingkat } \\
\text { Berpikir Kreatif }\end{array}$ \\
\hline $81 \%-100 \%$ & Sangat Baik \\
\hline $61 \%-80 \%$ & Baik \\
\hline $41 \%-60 \%$ & Cukup \\
\hline $21 \%-40 \%$ & Kurang \\
\hline $0 \%-20 \%$ & Sangat Kurang \\
\hline
\end{tabular}

Menghitung presentasi dan kualifikasi sebagai berikut

Persentasi kualifikasi $=\frac{\text { Skor perolehan }}{\text { skortotal }}=100 \%$

Uji Normalitas Data

Uji normalitas ini dilakukan untuk mengetahui apakah sampel yang diambil berasal dari populasi yang berdistribusi normal atau tidak. Rumus yang digunakan untuk uji normalitas adalah Shapiro-Wilk dengan bantuan SPSS 20.0.Pengambilan keputusan, jika Sig > 0,05 maka data berdistrubusi normal. Jika Sig < 0,05 maka data tidak berdistribusi normal. Dalam memudahkan dan mempercepat pengolahan data, penulis menggunakan komputerisasi dengan menggunakan progran sofware SPSS 20.0 .

\section{a. Uji Hipotesis}

Pengujian hipotesis dalam penelitian ini menggunakan one sample t-test, Pengujian ini dilakukan dengan bantuan sofware SPSS 20.0. Pembelajaran kooperatif tipe NHT dikatakan dapat meningkatkan kemampuan berpikir kreatif matematis siswa apabila rata-rata kemampuan siswa 80.80 .

Secara statiik dapat dituliskan sebagai berikut:

$$
\begin{aligned}
& \mathrm{H}_{0}: \mu_{N H T} \leq 80.80 \\
& \mathrm{H}_{1}: \mu_{N H T}>80.80
\end{aligned}
$$

\section{Keterangan.}


$\mathrm{H}_{0}$ : Tidak terdapat peningkatkan kemampuan berpikir kreatif matematis siswa pada materi lingkaran

$\mathrm{H}_{1}$ : Terdapat peningkatkan kemampuan berpikir kreatif matematis siswa pada materi lingkaran menggunakan Model pembelajaran kooperatif tipe NHT

Dengan kriteria pengujian:

Tolak $\mathrm{H}_{0}$ jika $\mathrm{t}$ hitung $>t_{\text {tabel }}$

Terima $\mathrm{H}_{0}$ jika t hitung $\leq t_{\text {tabel }}$

Untuk mendeskripsikan peningkatan kemampuan berfikir kreatif matematis siswa setelah diterapkan model NHT digunakan rumus Gain ternormalisasi ( $N$-gain) sebagai berikut:

$$
N-\operatorname{gain}(g)=\frac{(\text { skor rata }- \text { rata postest })-(\text { skor rata }- \text { rata pretest })}{\text { skor maksimum }-(\text { skor rata }- \text { rata pretest })}
$$

Setelah dilakukan pengujian dengan menggunakan rumus di atas, maka hasil yang diperoleh, dapat dikonversikan ke dalam kriteria $N$-gain (Sutarno dkk, 2010: 03). Kriteria rumus $\mathrm{N}$-gain tersebut disajikan dalam tabel berikut ini:

Tabel 2

Kriteria N Gain (g)

\begin{tabular}{|c|c|}
\hline Interval & Interprestasi \\
\hline$g>0,70$ & Tinggi \\
\hline $0,30<g \leq 0,70$ & Sedang \\
\hline$g \leq 0,30$ & Rendah \\
\hline
\end{tabular}

\section{HASIL PENELITIAN}

1. Deskripsi Kemampuan Berpikir Kreatif Mateamatis Siswa Setelah Diterapkannya Model Pembelajaran Number Head Together.

Data kemampuan berpikir kreatif matematis siswa Kelas VIII-ESMP Negeri 1 Kota Ternate yang diperoleh melalui tes awal (pretest) dan tes akhir (postest) sebelum dan sesudah penerapan model pembelajaranNumber Head Together dijelaskan pada Tabel 3 berikut.

Tabel 3

Kualifikasi Data Posttest Menggunakan PAP Skala 5

\begin{tabular}{|c|c|c|}
\hline Kualifikasi & Jumlah siswa & Presentasi \\
\hline Baik sekali & 9 & $39 \%$ \\
\hline Baik & 7 & $30 \%$ \\
\hline Cukup & 3 & $13 \%$ \\
\hline
\end{tabular}




\begin{tabular}{|c|c|c|} 
Kurang sekali & 2 & $9 \%$ \\
\hline Gagal & 2 & $9 \%$ \\
\hline
\end{tabular}

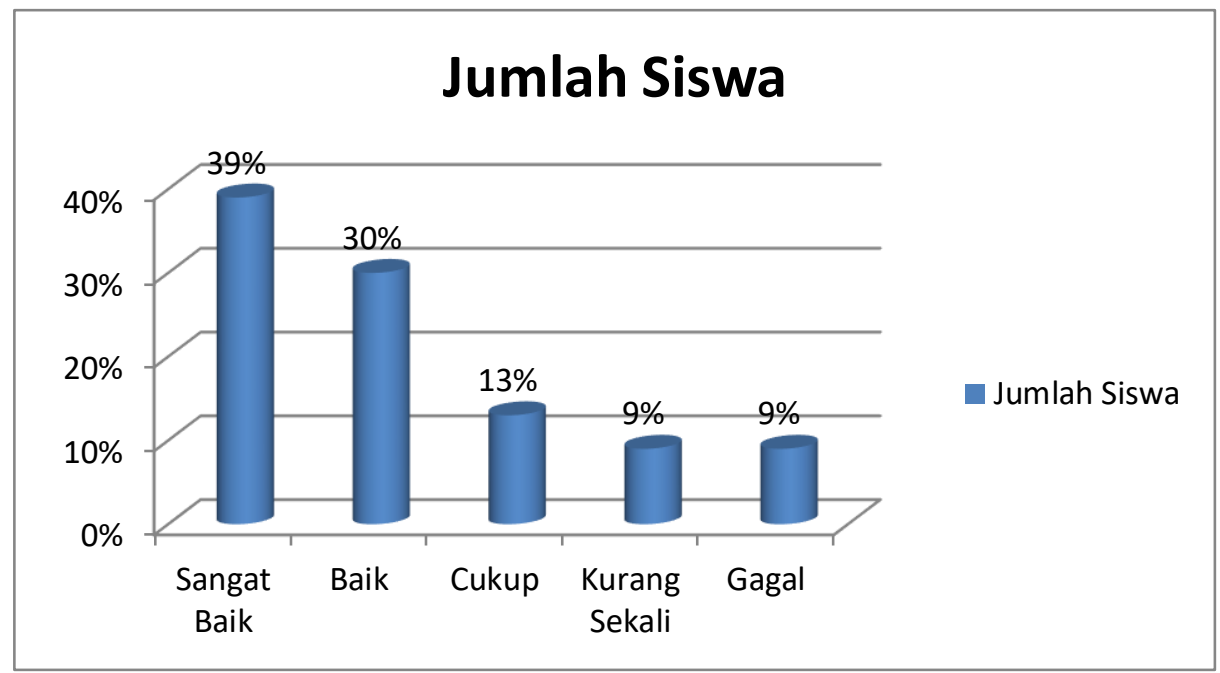

Diagram2.

Kualifikasi Data Posttest

Dari table 3 dan diagram 2 kualifikasi data posttest di atas menunjukkan bahwa kemampuan berfikir kreatif matematis siswa setelah diterapkannya model pembelajaran NHT diperoleh 39\% dikualifikasikan sangatbaik, 30\%, baik, 13\% cukup, 3\% kurang dan gagal yaitu $9 \%$.

2. Peningkatan Kemampuan Berpikir Kreatif Matematis Siswa Setelah Diterapkannya Model Pembelajaran Number Head Together (NHT).

Tabel4

Peningkatan Rumus N-Gain (g)

\begin{tabular}{|c|c|c|c|}
\hline Rata-rata Pretest & Rata-rata Posttest & N-Gain & Interpretasi \\
\hline 53,99 & 80.80 & 0,58 & Sedang \\
\hline
\end{tabular}

Data yang disajikan pada tabel dan diagram di atas menunjukan nilai rata-rata tes sebelum dan setelah pembelajaran Number Head Together (NHT) berturut-turut adalah 53.99 dan 80.80. Kemudian dari hasil komputasi diperoleh peningkatan kemampuan pemecahan masalah matematis siswa dengan menggunakan N-Gain yaitu sebesar 0,58 dengan interpretasi sedang. 


\section{Hasil Uji Peningkatan Kemampuanberpikir kreatifMatematisSiswamelalui Model pembelajaranNumber Head Together (NHT) pada materi lingkaran}

a. Uji Normalitas

\section{Tabel 5}

\section{Hasil Uji Normalitas Data}

Tests of Normality

\begin{tabular}{|l|l|r|r|r|r|r|r|}
\hline & \multirow{3}{*}{} & \multicolumn{4}{|c|}{ Kolmogorov-Smirnov } & \multicolumn{4}{|c|}{ Shapiro-Wilk } \\
\cline { 3 - 8 } & Keterangan & Statistic & \multicolumn{1}{c|}{ df } & \multicolumn{1}{c|}{ Sig. } & \multicolumn{1}{c|}{ Statistic } & \multicolumn{1}{c|}{ df } & \multicolumn{1}{c|}{ Sig. } \\
\hline Nilai & Pretest & .197 & 23 & .021 & .934 & 23 & .134 \\
& posttest & .204 & 23 & .014 & .916 & 23 & .054 \\
\hline
\end{tabular}

a. Lilliefors Significance Correction

Uji normalitasdilakukan dengan menggunakan program SPSS 23.0 for windows.Rumus yang digunakan untuk uji normalitas adalah Shapiro-Wilk.Pada pengujian normalitas didapatkan nilai signifikansidata adalah 0,134 dan 0,054 lebih besar dari 0,05 (sig. $>0,05$ ) sehingga dapat disimpulkan bahwa data berasal dari populasi yang berdistribusi normal.

\section{b. Pengujian Hipotesis}

\section{Tabel 6}

\section{Hasil Uji Hipotesis}

One-Sample Test

\begin{tabular}{|c|c|c|c|c|c|c|}
\hline & \multicolumn{6}{|c|}{ Test Value $=65$} \\
\hline & \multirow[b]{2}{*}{$\mathrm{t}$} & \multirow[b]{2}{*}{$\mathrm{df}$} & \multirow{2}{*}{$\begin{array}{l}\text { Sig. }(2- \\
\text { tailed })\end{array}$} & \multirow[b]{2}{*}{ Mean Difference } & \multicolumn{2}{|c|}{$\begin{array}{l}\text { 95\% Confidence Interval of the } \\
\text { Difference }\end{array}$} \\
\hline & & & & & Lower & Upper \\
\hline Posttest & 3.200 & 22 & .004 & 10.72435 & 3.7744 & 17.6743 \\
\hline
\end{tabular}

Berdasarkan uji normalitas di atas telah diketahui data dalam penelitianini adalah databerdistribusi normal, maka langkah selanjutnyamelakukan uji hipotesis. Dengan statistik uji yang digunakan adalah statistik uji parametrik yakni uji t satu sampel diperoleh nilai $t_{\text {hitung }}=3,200>t_{\text {tabel }}=2,073$ karenat $t_{\text {hitung }}>t_{\text {tabel }}$ dapat disimpulkan model pembelajaran kooperatiftipe NHT dapat meningkatkan kemampuan berpikir kreatif siswa pada materilingkaran.

\section{PEMBAHASAN}

Hasil penelitian yang diperoleh berdasarkan temuan-temuan peneliti dalam penelitian ini menggunakan model pembelajaran kooperatiftipe NHT dijelaskan di bawah ini.

\section{Kemampuan Berpikir Kreatif Matematis Siswa Setelah Diterapkannya Model Pembelajaran Koperatif Tipe Number Head Together(NHT)}


Berdasarkan analisis hasil penelitian, hasil tes kemampuan pemecahan masalah matematis siswa sebelum kegiatan model pembelajaran generatif memiliki nilai rata -rata 53.99 yang artinya hasil yang diperoleh belum mencapai kriteria tuntas secara klasikal. Sedangkan hasil yang diperoleh setelah kegiatan pembelajaran dengan model pembelajaran Koperatif Tipe Number Head Together (NHT) memiliki nilai rata-rata 80.80 yang artinya hasil yang diperoleh siswa sudah mengalami peningkatan. Dengan demikian, dapat disimpulkan bahwa nilai minimum dan maksimum hasil tes setelah diterapkannya model pembelajaran tersebut mengalami kenaikan. Hal ini dikarenakan dalam proses pembelajaran siswa secara kelompok saling membantu dan bekerja sama dalam menyelesaikan suatu masalah. Hal ini sesuai dengan apa yang disampaikan oleh Suyanto \& Jihad (2013: 134), Sebagai pembelajaran yang menekankan pada kerja sama, saling membantu, dan mendorong kegiatan diskusi dalam menyelesaikan tugas-tugas yang diberikan, model pembelajaran kooperatifNumber Head Together paling sesuai bila diterapkan dalam mata pelajaran matematika karena matematika merupakan pelajaran yang dinggap sulit dan memerlukan keaktifan dan kerja sama dalam menyelesaikan suatu masalah. Berdasarkan klasifikasi hasil tes setelah diterapkannya model pembelajaran kooperatif tipe dengan menggunakan kriteria kemampuan berpikir kreatifdiperoleh hasil persentasi yang berada pada interpretasi baik sekalidengan besar persentasi yaitu $39 \%$ dengan jumlah siswa sebanyak 9 orang, Persentasi baik interpertasi yakni sebesar30\% dengan jumlah siswa sebanyak 7 orang, sedangkan Persentasi cukup berada yakni sebesar 13\% dengan jumlah siswa sebanyak 3, orang, sedangkan Persentasi kurang sekali berada yakni sebesar 9\% dengan jumlah siswa sebanyak 2, orang, sedangkan Persentasi gagal berada yakni sebesar $9 \%$ dengan jumlah siswa sebanyak 2, orang.

\section{Terdapat Peningkatan Kemampuan Berfikir Kreatif Matematis Siswa Pada Materi Lingkaran Melalui Penerapan Model Pembelajaran Cooperatif Tipe NHT}

Terdapat peningkatan kemampuan berpikir kreatif matematis siswa setelah di terapkan Model pembelajaran Number Head Together (NHT) pada materi lingkaran, untuk uji normalitas data tes akhir dengan menggunakan programsofwareSpss diperolehsig. $0,054>$ nilai $\alpha=0,05$, artinya data atau sampelnya berdistribusi normal, sehingga digunakanuji statistik parametrik yaitu uji t. Dengandemikian berdasarkan nilai $\mathrm{t}_{\text {hitung }}=3,200 \mathrm{t}_{\text {tabel }}=2,080$ karna $t_{\text {hitung }}>t_{\text {tabel }}$ maka kesimpulannya Ho ditolak dan $\mathrm{H}_{1}$ diterima artinya terdapat peningkatan kemampuan berpikir kreatif matematis siswa pada materi sistem persamaan linear dua variabel melalui penerapan model pembelajaran kooperatif tipe NHT,

\section{Peningkatan Kemampuan Berpikir Kreatif Matematis Siswa Pada Materi Lingkaran Setelah Diterapkan Model NHT Menggunakan Rumus N-Gain}


Berdasarkan analisis data hasil penelitian, diperoleh bahwa nilai rata-rata pretest 53.99 dan posttest 80.80 dan diperoleh nilai N-Gain yaitu sebesar 0.58 , sehingga dapat dikatakan bahwa peningkatan hasil belajar siswa yang ditinjau dari kemampuan berpikir kreatif matematis siswa setelah diterapkannya model pembelajaran tipe Numbered Head Together (NHT) tergolong sedang.

\section{KESIMPULAN}

Berdasarkan hasil analisis data dan pembahasan, maka diambil kesimpulan sebagai berikut:

1. Keampuan kemampuan berpikir kreatif siswa siswa kelas VIII-E SMP Negeri 1 Ternate setelah diterapkan model Number Head Together (NHT) secara keseluruan dapat dilihat dari kualifikasinya yakni 39\% (9 orang) di kualifikasikan sangat baik, 30\% (7 orang) baik, 13\% (3 orang) cukup, 9\% (2 orang) kurang, dan gagal 19\% (2 orang).

2. Terdapat peningkatan kemampuan berpikir kreatif matematis siswa setelah di terapkan Model pembelajaran tipeNumber Head Together (NHT) pada materi lingkaran.

3. Peningkatan kemampuan berpikir kreatif matematis siswa kelas VIII-E SMP Negeri 1 Kota ternate setelah diterapkannya model pembelajaran kooperatif tipeNumber Head Together (NHT) yaitu 0,58 yang diinterpretasikan sedang. 


\section{DAFTAR PUSTAKA}

Djamarah, S. B. \& Zain, A. 2002. Strategi Belajar Mengajar. Jakarta: PT. RINEKA CIPTA.

Fauziyah, I.N.L., Usodo, B., Ekana Ch, H. 2013. Proses Berpikir Kreatif Siswa Kelas X Dalam Memecakan Masalah Geometri Berdasarkan Tahapan Wallas Ditinjau Dari Adversity Quantient (Aq) Siswa. Jurnal Pendidikan Matematika, Vol. 1, 79-89

Hasbulah. 2011. Dasar-Dasar Ilmu Pendidikan. Jakarta: PT. RajaGrafinDo Persada.

Ika, H. 2014. Penerapan Model Pembelajaran Berbasis Masalah untuk Meningkatkan Bepikir Kreatif Matematis Siswa TKJ pada Pelajaran Jaringan Dasar di SMK. Jurnal Ilmiah Pendidikan Teknik Elektro, Vol(3), No 4, 3-9.

Sahrudin, A. 2014. Implementasi Strategi Pembelajaran Discovery Untuk Meningkatkan Kemampuan Pemecahan Masalah Matematis Dan Motivasi Belajar Siswa SMA. Jurnal, pendidikan UNSIKA, ISSN: 2338-2996. 